\title{
Veblen, Braudel ve Foucault ile Neoliberal iktidara Karşı Yeni Bir Teknoloji ve Maddi Kültür Perspektifine Doğru
}

\section{CEYHUN GÜRKAN ${ }^{1}$}

${ }^{1}$ Assoc. Prof. Dr., Ankara University, Department of Public Finance (Orcid ID: 0000-0002-8048-7175)

\begin{abstract}
Özet
Bu yazı Thorstein Veblen, Fernand Braudel ve Michel Foucault'nun maddi yaşam, maddi kültür ve teknoloji üzerine yaklaşımlarını inceleyerek neoliberal iktidarın eleştirisi için bir düşünce hattı geliştirmeyi amaçlamaktadır. Disiplinler-ötesi bir yaklaşıma sahip çıkan bu inceleme maddi kültür, maddi/gündelik yaşam ve teknoloji ilişkisini toplumsal değişim, iktidar ve kapitalist ekonominin yapısı bağlamında mikro ve makro düzeylerde aralarındaki ilişkinin unsurlarını ve dinamiklerini göstermekte ve açıklamaktadır. Yazı teknoloji ve maddi kültür ilişsisini toplumsal değişim ile süreklilikler ve süreksizlikleri içeren çoğul süreçler meselesi olarak ele almaktadır. Bu değişim ve süreçleri yorumlayan ve açıklayan bir yaklaşım olarak önce Veblen'den hareketle kurumsalcı ve evrimselci bir çerçeve çıkarılmışır. Braudel'den hareketle yapısal ve global tarih anlayışı çerçevesinde konu incelenmekte; ardından konu Foucault'nun politik rasyonalite ve iktidar ilişkileri ile kiplerinin çerçevesine taşınmaktadır.
\end{abstract}

Anahtar Kelimeler: Veblen, Braudel, Foucault, maddi kültür, teknoloji

Corresponding Author / Sorumlu Yazar

E-mail / E-posta

Manuscript Received / Gönderim Tarihi

Revised Manuscript Accepted / Kabul Tarihi

To Cite This Article / Kaynak Göster

\section{CEYHUN GÜRKAN}

Ankara University, Department of Public Finance

cgurkan@politics.ankara.edu.tr

August 13, 2020 / 13 Ağustos 2020

October 29, 2020 / 29 Ekim 2020

Gürkan, C. (2020). Veblen, Braudel ve Foucault ile Neoliberal İktidara Karşı Yeni Bir Teknoloji ve Maddi Kültür Perspektifine Doğru. ViraVerita E-Journal: Interdisciplinary Encounters, Sayı 12, 167-192. 


\title{
Towards a New Perspective for Technology and Material Culture against Neoliberal Power with Veblen, Braudel and Foucault
}

\begin{abstract}
This article aims to develop a line of thinking for the critique of neoliberal power by examining the approaches of Thorstein Veblen, Fernand Braudel and Michel Foucault on material life, material culture, and technology. This study, which adopts a transdisciplinary approach, shows and explains the elements and dynamics of the relationship between material culture, material/everyday life, and technology in the context of social change, power, and the structure of the capitalist economy at micro and macro levels. The article discusses the relationship between technology and material culture as a matter of social change and multiple processes involving continuities and discontinuities. First, as an approach that interprets and explains these changes and processes, an institutionalist and evolutionary framework is created based on Veblen. Based on Braudel, the subject is examined within the framework of a structural and global conception of history; in turn, it is moved to the framework of Foucault's account of political rationality, power relations, and the modes of power.
\end{abstract}

Keywords: Veblen, Braudel, Foucault, material culture, technology 


\section{Veblen, Braudel ve Foucault ile Neoliberal İktidara Karşı Yeni Bir Teknoloji ve Maddi Kültür Perspektifine Doğru}

\section{Giriş}

Modern toplumsal düzenin sacayağı ve ilkesi olarak kabul edilen devlet, (sivil) toplum ve piyasanın birbirleriyle karmaşık ilişkileri içinde birlikte ortaya çıkardıkları yapı on sekizinci yüzyılın son çeyreğinden itibaren sosyal bilimlerin disiplinlere bölünmüş bünyesi çerçevesinde araştırılan ve anlaşılmaya çalışılan temel konudur. Bu yapının öznelerinin ve aktörlerinin çözümlemelerde kazandıkları ağırlık bireysellikten kolektif oluşumlara kadar çeşitlilik göstermiş ve toplumsal düzenin oluşumu esas olarak tanımları değişen bireyler ve topluluklar arasındaki çelişkili ilişkiler ya da bu çelişkiden doğan uyumsal durum etrafında kavramsallaştırılmıştır. On sekizinci ve on dokuzuncu yüzyıla yayılan iktisadi, teknolojik ve siyasal devrimleri yirminci yüzyılın iki dünya savaşı izlemiş ve 1960'ların sonundan itibaren bu savaşlar sonrasında kurulan dünya iktisadi sisteminin kriz durumlarını 1990'lardan sonra neoliberalizm olarak adlandırılan küresel ölçekteki yeni düzenin siyasal yapısının tam gelişimi, kendi içinde dönüşümleri ve nihayetinde bugün küresel düzeyde içinden geçilen bu siyasal yapının krizleri takip etmiştir. On sekizinci yüzyıldan bugüne devlet, (sivil) toplum ve piyasa arasındaki toplumsal düzenin temel ilkelerinin kendi içlerinde ve birbirleriyle ilişkilerinden doğan bütünsel kriz durumlarının genel olarak iki yönlü bir analize tabi tutulduğu söylenebilir. Dönüşümler ya iktisadi dinamiklere ve süreçlere ağırlık veren kapitalizmin gelişimi ve krizleri bakımından incelenmiş ya da siyasal dinamiklere ve süreçlere ağırlık veren liberalizmin gelişimi ve krizleri bakımından ele alınmıştır. İşleyişte birbirinden ayrılması güç olan bu iki kriz durumu karşısında sosyal teoride geliştirilmiş kuramsal ya da ampirik analizler iki kriz durumundan birine ve bunun dinamiklerine ağırlık vermiştir. Bu analizler çoklu kriz durumları karşısında ya yetersiz kalmış ya da iktisadi, siyasi, kültürel sorunlar ile iklim, çevre, sağlık, göçmen/mülteci sorunları gibi süreçleri içinde taşıyan bileşik kriz durumlarını anlamak için işlevsiz olmuştur. Bunun diğer bir nedeni ise toplumu anlamada dayanak olan kuramsal ve yöntemsel anlayışlar ve yaklaşımlardır. Sosyal bilimlerin disipliner bölünümüyle sonuçlanan bu anlayışlar ve yaklaşımlar toplumu anlamada ikiliklere dayanan kuramsallaştırmaları, ekonomizmi ve iktisadi indirgemeciliği, iktisadi ve teknolojik determinizmi, teleolojik yaklaşımları, statik sınıflandırmaları (taksonomi), kolonyalist 
düşünceleri ve kavramsallaştırmaları, yöntemsel bireyciliği, yöntemsel ulusçuluğu, yöntemsel teritoryalizmi, devlet-odaklı yaklaşımları içinde taşımıştır. Sonuç, toplumu salt ulus ve toprak birliği içinde, kültürel ya da politik olarak homojenleştirilmiş insanlar arası ilişkiler olarak kavrayan, insan birlikteliğini ve ilişki ağını teknisist nüfus düzleminde kavrayan kuramsal yaklaşımlar olmuştur.

İçinden geçilen çoklu ve birbirine eklemlenen kriz durumları karşısında ulusal ve ulusötesi çerçevede toplumu çözümlemeye dönük yaklaşımlar kapitalizmin ve liberalizmin çakışan kriz durumunu anlamlandırmaya yönelirken yukarıda sayılan yöntemsel kısıtlardan uzaklaşmaya çalışmaktadır. Bu çabalarda göze çarpan yeni yaklaşımların arasında ulus-ötesi (transnational) yaklaşımlar, aktör-ağ teorisi (actor network theory), insan-sonrası (post-human) yaklaşım, yeni materyalizm (new materialism), post-kolonyal sosyoloji, post-kolonyal politik ekonomi, kalkınma-sonrası (post-development) yaklaşımlar, küçülme (degrowth) teorisi ve maddi kültür çalışmaları özellikle dikkat çekmektedir. Marx'tan Foucault'ya ve günümüze klasik ve çağdaş sosyal, siyasal ve ekonomi politik kuramları eleştirerek değişen ölçeklerde benimseyip bünyesine katıp ilerleyen bu yeni çabalar özellikle insan birlikteliğini ve bu birliktelikten doğan toplum durumunu yeni yöntemsel ve kavramsal araçlarla açıklamaya ve kuramsallaştırmaya çalışmaktadır. Toplumu insan-merkezli, salt insanlar arası birliktelik ve insanın doğaya karşı üstünlüğü temelinde antroposentrik olarak açıklamanın ötesine geçen; antroposen çağın siyasal yapıları olan ulus, halk, nüfus ve devlet gibi bütünsel ve bütünselleştirici yapıları kolonyalist içeriklerinden arındırarak yeniden anlamlandıran ve eleştiren; toplumu devlet, toplum ve piyasanın ötesinde maddi olanla ilişkileri içinde birlikler ve ağlar çerçevesinde değerlendiren; insan-insan ilişkisinin ötesinde insan-madde ve insan-doğa ilişkisine ön planda yer açan; endüstriyel, ticari ve finansal kapitalizmin eleştirisini yeni toplumsal durumlar içinden ve tekno-bilimsel emperyal bilme biçimlerine ve bilgi yapılarına uyum sağlamış disipliner bölünmenin ötesine geçerek anlamaya yönelen bu yeni çabalarda birbiriyle ilişkisi içinde ön plana getirilmesi gereken dört unsur göze çarpmaktadır: teknoloji, madde, gündelik yaşam, iktidar.

Sıralanan bu dört unsuru yeni kılan kavramsallaştırma düzeyinde bilinmemeleri değildir. Eksiklik bu dört kavramın hem kendi içlerinde hem birbiriyle ilişkileri çerçevesinde anlamlandırılma ve daha iyisi kuramsallaştırılma çabalarında yatmaktadır. Teknolojiyi bir 'kara kutu' (black box) gibi içinde ne olduğunu bilmeden anlamaya dönük geleneksel yaklaşımların eleştirisi olarak yükselen ve kara kutuyu açarak teknolojiyi salt insanın kapitalistik yetkinliği ve 
etkinliği kapsamında bir inovasyon teorisi olarak açıklayan çağdaş yaklaşımlar, kapitalizmin ve liberalizmin çakışan krizi durumlarında çoktan sorgulanması gereken teoriler hanesine taşınmıştır. Teknolojiyi deterministik ve insan yaşamına yalnızca dışarıdan etkide bulanan dışsal bir güç olarak kavrayan, kara kutunun içindeki sosyal unsurları tarihin belli noktasında gelişmiş kapitalist kurumlara ve düşünce alışkanlıklarına indirgeyen yaklaşımlar insanın teknolojiyle olan uzun dönemli tarihsel ilişkisini, teknoloji aracılığıyla ürettiği ürünleri/maddeleri ya da maddi yaşamı doğru ve daha önemlisi değişime yönelik bir düşünceyle açıklayamama sonucunu doğurmaktadır. Bu durum ve sonuç teknoloji, madde, maddi yaşam ve insan arasındaki iktidar ilişkilerini de görünmez kılmaktadır. Dolayısıyla, iktidar da geleneksel olarak makro ve mikro düzlemlerde insan merkezli, salt insan-insan ilişkisi çerçevesinde anlaşılmaktadır. Oysa iktidarın materyalist açıklaması ve teorisi makro ve mikro düzlemlerde insan-insan ilişkisinin ötesinde insan-madde ilişkisini de konu edinmelidir. Önce iş̧̧i sınıfının daha sonra tüm toplumsal yapıya yayılacak şekilde insanın endüstriyel teknoloji ile ürettiği ve ulusal/uluslararası pazarlar aracılığıyla dolaşıma soktuğu meta formundaki ürün/madde teorisi kapitalist iktidar teorisinin bir yönünü, toplumu iktisadi olarak yöneten hâkim iktidar paradigması yönünü güçlü bir şekilde açıklamaktadır. Kültürel ve siyasal yapıların ve onların yönetimi bu kapitalist yapıdan ayrı görülemese de, bu yapıların bütünüyle ona indirgenerek açıklanması da sorunludur. Maddenin insan karşısında ya pasif ya da insandan bağımsızlaşıp ona dışsal olarak iktisadi olarak hükmetmesi teorisinin ötesinde siyasal ve kültürel açıdan farklı kuramsallaştırma ve kavramsallaştırma denemelerine kulak vermek yararlı olacaktır. Bunun temel nedenlerinden biri de refah sistemlerinin içi boşaltılırken refah devleti modelindeki metasızlaştırma süreçlerinin uğradığı dönüşüme koşut olarak bireylerin endüstriyel kapitalizmin ve pazarların dışına çıkıp/çıkarılıp en eski tekniklerle ve ürünlerle, değişim yolları ile yeniden buluşmalarında artan hız ve yoğunluktur.

Covid-19 salgın dönemi yukarıda sıralanan düşüncelerin ve yeni yaklaşımların doğruluk payını belli ölçüde göstermiştir. Salgın, yarattığı sonuçlar itibarıyla sadece doğa üzerinde tahripkâr hâkimiyet kuran emperyal tekno-bilimsel antroposen çağın bir olumsuzluğu olarak değil, toplumun siyasal ve iktisadi yapısının insan-insan ilişkisine sığmayacak bir birliktelik durumu olduğuna da işaret etmiştir. Bu sonuçlar arasında insanın kapitalist piyasa ve üretim tarzından hızlıca çıkmaya ne denli eğilimli olup, gündelik maddi ve kültürel yaşamına çekilirken hızlıca eski üretim ve teknoloji araçlarıyla yeniden bütünleşip ürünleriyle alım-satıma dayanmayan dostane bir ilişki kurması da yer almaktadır. İktisadi kriz durumlarında sıkıkla 
görülen halkın kısa sürede para ekonomisinden çıkıp doğal ekonomi ve trampa düzenine dönmesi gibi maddi yaşamın üretimi ve teknolojiye yaklaşımı da dönüşmektedir. Endüstriyel ve finansal kapitalizmin yeni teknolojik ürünlerinin karşısında piyasa değeri olmayan veya piyasa diğeri çok düşük olan ürünler etrafında ihtiyaç temelli bir ekonomi ve ekonomi algısı gelişirken kapitalizmin bu alanlara kalkınma sorunsalı ve/veya yoksullukla mücadele adı altındaki kapitalist müdahalesi kendisine yönelecek olan tepkiyi ve hıncı yönetmeye dönüktür. Piyasa kapsamı ve değeri bakımından belki önemsenmeyecek mikro düzeyde gündelik ürünlerle (örneğin virüsten korunmak için evde yapılan maskeler gibi) sınırlı olsa da söz konusu algının ve pratiğin kapitalist piyasa ekonomisine ve kurumlarına itirazı piyasanın fiyat sistemi ile ölçülen ürünlerin değerinden aslında çok daha yüksek düzeydedir. Krizlerde insanlar maddi yaşamın derinlerine çekilme eğilimini gösterdikçe bu algı ve küçük pratikler kalıbına sığmayan bir sosyal ve politik itiraza dönüşme potansiyelini taşımaktadır. Bu bakımdan siyasal iktidarların piyasa değeri düşük ürünler etrafında sosyal ilişkileri yönetme stratejileri büyük ölçekli "işler"in önüne geçebiliyor. Illeri teknoloji ve küresel kapitalizm çağında böyle bir kapitalist piyasanın dışındaki alanın son derece daralmış olduğu düşünülebilir ancak kapitalist tahakkümünün maddi yaşamın derinliklerine inmesi onu daraltması olarak değil, kapitalizme karşı mücadelenin derinleşen ve yoğunlaşan alanı olarak anlaşılmasını gerektirmektedir. Bu alan piyasa ekonomisinin ve küresel yüksek kapitalizmin altında ve ötesinde onlara karşı maddi yaşamın ve kültürün itiraz yüklü enerjisinin biriktiği bir yüzeydir. Burada yalnızca dünya nüfusunun neredeyse yarısına tekabül eden kırsalda yaşamını sürdüren ve hepsi için geçerli olmasa da ilkel teknolojik araçları kullanan insanları kastetmiyoruz; aynı zamanda kent yaşamı ve ekonomisi içinde ve çeperlerinde piyasa ekonomisi ve küresel yüksek kapitalizmle iç içe, karşı karşıya, yan yana yaşayan, ileri teknolojiyi kullanan ancak farklı ve karşıt kültürel ekonomi ve teknolojik yaklaşımlar geliştiren büyüyen bir nüfustan bahsediyoruz.

Bu çalışma siyaset, ekonomi, jeopolitik, iklim, çevre, sağıı, toplumsal cinsiyet, göçmen/mülteci sorunlarıyla çeşitlenen, kültürel ve kimlik çatışmalarıyla çok yönlü kriz durumlarının iç içe geçerek birbirini beslediği bir dünya zamanı ve ortamında yeni eleştirel yaklaşımların dikkat çektiği üç unsuru üç sosyal bilim insanı ile açıklamayı denemektedir: maddi ve gündelik yaşam, teknoloji ve iktidar. Maddi kültür ve teknoloji çalışmaları özellikle arkeoloji ve antropoloji alanında kök salmış olmasına karşın sosyoloji ve ekonomi politik temelli sosyal teorinin de ilgi alanında olmuştur ancak genişletilmeye ihtiyacı vardır. Bu yazı maddi yaşamı ve kültürü tarihsel sosyolojiye ve iktisat tarihine dâhil eden isimlerden Fernand Braudel, 
teknolojinin toplumsal teorisinin öncü ismi Thorstein Veblen ve iktidarın politik sosyolojisinin yeni açıklamasını ve analitiğini geliştiren Michel Foucault ile madde, maddi ve gündelik yaşam, teknoloji ve iktidar ilişki ağına bir açıklama sunmaya çalışmaktadır. Konunun sunulabilir bir yazı çerçevesinde yol alabilmesi için ortaya çıktıkları tarihsel sıraya da uygun olarak Veblen, Braudel ve Foucault ele alınacak; sonuç bölümünde burada çizilen sorunsal çerçevesine bağlanan maddi kültür-yaşam-teknoloji ilişkisinin neoliberal iktidara karşı yeni bir kuramsal anlayış kalıbına nasıl dökülebileceğini özetleyen kısa bir değerlendirme sunulacaktır.

\section{Veblen ve Teknolojinin Toplumsal Teorisi}

Veblen'in teknolojiye yaklaşımı kendisinin teknolojiye getirdiği tanımdan anlaşılmaktadır. Teknoloji, Veblen'e göre, fiziki bir makine-teçhizat varlığından önce insanlığın ortak bilgi stokudur ve modern sanayinin dayandığı teknoloji de bu gerçeğin dışında değildir:

Teknolojik bilgi topluluğun elinde kolektif olarak ileriye taşınan ortak maldır; bu
[ortaklaşa] ilişki içinde süregiden başarılı bir iş olarak görülmelidir. Endüstriyel
zanaatların bugünkü durumu da bir grup yaşamı gerçeğidir, bireysel ya da özel
girişimin veya inovasyonun değil. Kolektivitenin bir sonucudur, özel mülkiyet ya da
izolasyon içinde kendine yeter şekilde çalışan bireylerin yaratıcı bir başarısı değildir.
Esasen, endüstriyel zanaatların gelişim düzeyi her zaman geçmişten gelen bir
mirastır; her zaman değişim süreci içindedir, fakat belki de esas gövdesi daha eski
kuşaklardan gelen bilgidir. Bu ortak mala şimdiki kuşağın deneyimi ve girişimi ile
kavrayışın ve ustalığın yeni unsurları eklenir ve geliş̧imi sağlanır; fakat bu tür yeni
unsurlar geçmişten taşınan teknoloji yığını ile karşılaştırıldığında her zaman ve her
yerde hafif ve önemsizdir (Veblen, 1946, s. 103).

Veblen'in 'ebeveynlik' ve 'aylak merak' içgüdüsü yanında topluluğun üç kurucu güdüsünden biri olarak tanımladığı 'ustalık' içgüdüsü insanın kolektif ve maddi yaşamı içinde teknoloji yaratma yatkınlığının ana kaynağıdır. İnsanın yeni bilgi arayışının temel yönelimine işaret eden 'aylak merak' içgüdüsüne bağlı olarak teknoloji, bireyin yaratmaya dönük içgüdüsel bir yatkınlığıdır. Ancak teknoloji, bireyin grup yaşamına ve bu grup içinde korunma ve refah elde etme yatkınlığını ifade eden ebeveynlik içgüdüsü gibi kolektif eğilimlerinden ve eski kuşaklardan beri yerleşik duruma gelmiş 'düşünce alışkanlıkları'ndan (habits of thought) bağımsız değildir. Bireysel yatkınlıklar ancak grup yaşamı içinde gerçekleşir. Veblen'in sözleriyle:

Peş peşe gelen her hareket, yeniliğin, gelişmenin, icadın, adaptasyonun tüm yeni teknik girdisi, ustalıklı inovasyonun her detayı elbette bireyler tarafından hazırlanır ve bireysel tecrübeden ve girişimden doğmaktadır; çünkü insan nesli yalnızca bireylerde yaşamaktadır. Ne var ki, bu tür her hareket mutlaka topluluğa gömülü bireyler tarafından gerçekleştirilir ve toplulukta yaşandığı şekliyle grup 
yaşamının disiplinine tabidir; çünkü tüm yaşam mutlaka grup yaşamıdır. İnsan yaşamı olgusu yalnızca bu formda oluşur. ... Büyük ya da küçük olsun, bir şekilde bulunan her araç veya yenilik grubun elindeki teknolojik kaynakların ortak stokuna dâhil olduğunda yürürlüğe girmektedir (Veblen, 1946, s. 103-104).

Dolayısıyla, teknoloji topluluk yaşamının sonucu olup yine topluluğun elinde ortak mülkiyetin konusu olduğunda etkinlik kazanmaktadır. Teknolojinin bu tanımına göre teknoloji topluluk yaşamının ortaklaşa eyleminden ve maddi kültüründen doğar; yine bir ilerleme hareketi olarak teknoloji topluluğun kültürü, eylem tarzları, değerleri ve normları, kuralları, düşünce alışkanlıkları, kısacası kurumlar üzerinde etkide bulunur. Burada söz konusu olan etki kurumların her teknolojik yenilikle mutlaka dönüşeceği anlamındaki teknolojik determinizme göndermede bulunmamaktadır. Illkel toplumlar için geçerli olan bu gözlem modern sanayi toplumları için de doğrudur. Almanya ve Japonya'nın sanayileşmelerini incelediği çalışmalarında Veblen $(1964 ; 1994)$ on dokuzuncu yüzyıldaki teknolojik hamlelerin bu ülkelerin hanedanlık yapısı içindeki geleneksel kurumlarla yan yana gerçekleştiğini belirtir. Dolayısıyla toplumsal değişimin hızını ve yönünü tayin eden dinamik bir kurum olarak teknoloji geleneksel kurumlarla çelişkili ve çatışmacı bir ilişki içinde olabileceği gibi onlarla uyum gösteren bir ilerleme ve değişim çizgisinde de kalabilir. Değişime karşı, değişimi durduran geleneksel kurumları sürekli çözmeye çalışan dinamik bir kurum olarak teknoloji kolektif yaşamın maddiliği ve bunu besleyen insanın temel barışçı içgüdüsel yatkınlıklarından doğsa da, aynı zamanda insanın yağmacı ve savaşkan içgüdüleri ve bunların somut kurumları, teknolojinin bu değişime yönelik yapısıyla sürekli mücadele halindedir. İnsan teknoloji ile kendini ve topluluğunu yaratırken aynı zamanda yine topluluğun içinden doğan yağmacı ve savaşkan içgüdülerle, kültürle, kurumlarla ve bunun özneleriyle, bu öznelerin elinde şekillenen değişimi durdurucu 'ahmak' (imbecile) teknolojik yaratım ve kullanma kültürü ile sürekli savaş halindedir. Teknoloji Veblen'in toplumsal değişim teorisinde diyalektik toplumsal ilişki ağı içinde değerlendirilmiş ve değişime kolektif şekilde yön veren maddi kültürle şekillenen dinamik bir kurum olarak karşımıza çıkmaktadır. Ancak teknolojiyi ve kaynaklarını bireysel sahiplik kültürü ve kurumuyla ele geçiren muhafazakâr girişimler teknolojiye ilerleme hareketi içinde değişimi durdurucu bir yapı ve özellik kazandırmaktadır. Bu bağlamda, teknoloji olarak modern devlet aygıtları ve askeri yenilikler ilk akla gelenler olsa da, Veblen için bunun modern zamanlardaki temel kurumu, özel mülkiyeti temel norm haline getirmiş liberal (doğal) hukuk ile topluluğun ortak teknolojik faaliyeti ve stoku üzerine ipotek koyan, bu ipoteği yüksek fiyatlarla kısa vadede kâr elde etmek için baltalayan (sabotage) kapitalistlerin yarattığı firma ya da ticari girişimdir. 
Modern çağda Veblen açısından çelişkinin tarafları makine teknolojisine dayalı maddi kültür ve materyalist düşünce alışkanlıkları ile ticari girişimin fiyat sistemi çerçevesinde örgütlediği ve gerektiğinde teknolojik gelişimi durduran ve baltalayan kapitalist sınıf ve kültürdür. Kapitalizm teknolojinin yaratımı ve organizasyonu ile teknolojinin kullanım tarzı ve teknoloji kullanılarak üretilecek ürünlerin seçimini ve bunların tüketim yolunu ve kültürünü, liberalizmin hukuksal soyut ilkeleri temelinde bireysel özel mülkiyet sistemi içinde gerçekleştirmektedir. Özel mülkiyet sistemi teknolojinin yaratım, sahiplik ve kullanım boyutlarında toplumsal doğasına kayıtlı kolektif özelliklerini bireyselleştirir. Firma ve ticari girişim bir topluluk olarak kapitalistlerin karşısındaki birlikleri çözen ve bireyselleştiren örgütlü çıkar çevreleridir (vested interests). Bu örgütsel ve kültürel boyutun yanında temel araç piyasa sistemi içerisindeki fiyat sistemi ve bu fiyat sisteminin işleyişini mümkün kılan bilgi ve inanç sistemleridir. Toplumda ustalık içgüdüsüne bağı gelişen ve ebeveynlik içgüdüsü ile kolektif bir eyleme dönen teknolojik üretim ve teknolojinin maddi (material) kültürü karşısında 'parasal' (pecuniary) kültürün spekülatif ve soyut bilgi ve metafizik inanç sistemleri barışçıl teknolojik gelişimi ve toplumsal değişimi durduran ahmak ve yağmacı kurumsal tertibatı oluşturmaktadır. Özel mülkiyet sistemi içinde gerçekleşen sanayi devriminin izinde gelişen modern iktisat, özellikle on dokuzuncu yüzyılın son çeyreğinde yarattığı marjinalist dönüşüm, toplumda iş birliğine dayalı teknolojik üretimin maddi kültürü karşısında spekülatif fiyat sisteminin muhasebe alışkanlığını yayan temel bilgi ve inanç sistemi olarak, Veblen'in (2017d; 2017e) eleştirisinin değişmez hedefi olmuştur. Bu yapı on sekizinci yüzyılın birinci sanayi devriminden on dokuzuncu yüzyılın ikinci sanayi devrimine uzanan ve yirminci yüzyılda büyük ölçekli kitlesel üretimin makine teknolojisi çağından çok önce eski toplumların ilkel yabanıl kültürüne kök salmış derin bir kurumsal ve yönetimsel düzenektir. Veblen ilkel toplumlarda kahramanlık ve maskülen egemenliği kapitalistik yağmacı kültürün başlangıç koşullarından biri olarak değerlendirmektedir. Zora dayalı, yağmacı, maskülen kahramanlık kültürü kadınları evlilikler yoluyla ele geçirilen meşru bir ganimet olarak görüp baskıcı bir özel mülkiyet tertibatı içine yerleştirmiştir. Bu evlilik kurumunun uzantısı maskülen gücün dışavurumunun aracı olarak israfçı ve gösteriş̧̧i tüketim ile süs eşyaları ve kadınların kıyafeti, özel mülkiyet kültürünün ve düşünce alışkanlıklarının kökeninde yer almaktadır. Birikimli nedensellik süreci içinde evrimsel bir gelişim sergileyen bu yabanıl yağmacı kültür toplumsal yapının bütününe yayılarak taklit ve öykünme süreci içinde topluluk yaşamının diğer kurumlarına bulaşmıştır. Teknolojinin ve üretilen ürünlerin ihtiyaç ekonomisinin ötesinde kadın ve erkek arasındaki zora ve güce dayalı 
mülkiyet-evliliğinin kurumsal yapısının ve kültürünün ahmak kurumu haline gelmesi özel mülkiyet sisteminin başlangıç koşullarını oluşturmuştur (Veblen, 2017a; 2017b; 2017c). Toplumların evrimsel süreci içinde hukuk, din ve ekonomi kadın üzerindeki ataerkil iktidarı üreten ve bu yolla teknolojinin barışçıl ortaklaşa maddi kültürünü baskılayan, bireysel sahipliği ve özel mülkiyetin kurucu ilişkilerini oluşturan, ürünleri bunun simgesi ve statü göstergesi olarak kodlayan, teknolojiyi bu yolla kullanan ve örgütleyen genel bir inanç ve bilgi sistemi inşa etmiştir. Veblen'in teknoloji, kapitalizm ve iktisat eleştirisini bu antropolojik kültür eleştirisi temelinde anlamak gerekir. Dolayısıyla evrimselci ve kurumsalcı iktisat teorisinin temelleri bu kültürel düzlemde anlaşılmalıdır.

Veblen gelişimine tanıklık ettiği makine teknolojisine dayalı sanayi sistemini, bu uzun tarihi değiştirecek potansiyelde görerek iyimser bir tutum sergilemiştir. Örneğin Veblen (2017c, s. 68) modern sanayi sisteminin materyalist ve kolektif kültürü geliştirdiğini ve buna bağlı olarak aynı zamanda bireysel sahiplik ve mülkiyet sisteminin temelinde gördügü aile kurumunun boşanmaların artışı ile zayıflamasını tespit eder ve yirminci yüzyılda yeni gelen kuşakların endüstriyel materyalist bir yaşam disiplini içine girerek materyalist düşünce alışkanlığı içinde somut ve gerçek birikimli neden-sonuç ilişkilerini anlamaya başladıklarını düşünmektedir. Modern sanayi sistemini oluşturan makine teknolojisi Veblen'e göre teknoloji ve insan birlikteliğinin özsel doğasına adeta bir dönüş imkânı tanımaktadır. Şöyle yazmaktadır: "Modern kültürde sanayi, sanayi süreci ve sanayi ürünleri insan doğasıyla örtüşmüştür. ... Bunlar bireyin günlük hayatını ve dolayısıyla düşünce alışkanlıklarını şekillendiren en önemli unsur haline gelmiştir. Bu bakımdan, birey teknolojik süreçlerde oluşan kavramlarla düşünmeyi öğrenmiştir" (Veblen, 1961, s. 17).

Makine teknolojisine dayalı modern sanayi kapitalist mülkiyet sistemi içinde tutulup, kârlı fiyatlar için yeri geldiğinde toplumun maddi refahı pahasına sabote edilerek ' gelişimi durdurulsa bile modern teknolojinin toplumun bütününe yaydığı materyalist düşünce alışkanlıkları kapitalizmin parasal kültürünü yerinden etme potansiyeline fazlasıyla sahiptir. Gündelik yaşamdaki 'sıradan insan' (common man) ile teknolojinin üretimini, kullanımını ve organizasyonunu üstlenen mühendislik bilgisini haiz uzman sınıf arasında kültürel ve düşünce alışkanlıkları açısından mesafe gittikçe kısalacaktır. Veblen (2001) açısından mühendis sınıfın öncülüğünde kurulacak teknisyenler sovyeti bu değişimi bilinçli ve kararlı bir siyasi ve iktisadi programa dökecektir. Veblen için bu bir öngörü olmakla beraber 1920'lerin içinden baktığında henüz o saatin gelmediğini ayrıca vurgulamaktadır. Modern teknolojinin fordist kültürü, siyasal 
yapısı ve teknolojik işleyişi içinde güçlü ve teknik açıdan ehil bir işçi sınıfı yaratmış ve teknolojinin 1980'lerdeki finansal kapitalizm ii ile iç içe geçen yeni neoliberal dönüşümünün bu maddi kültüre yönelik bir karşı-devrim olarak doğduğu Veblen açısından söylenebilir. Dolayısıyla 1980 sonrası günümüze dijital teknoloji ve büyük veri paradigması olarak ulaşan dönüşümün altında Veblen'in barbar toplumlara dek izini sürdüğü iki kültürün -barışçl dinamik maddi kültür ile gelişmeyi durduran yağmacı ahmak metafizik/spekülatif kültür- aralarındaki çatışma yatmaktadır. 1980 sonrası büyük teknolojik ilerleme ile gelişmenin durduğunu söylemek makul görünmeyebilir. Ancak akla yatkın olan bir şey varsa o da Veblen'in tezini doğrular şekilde bu iki kültürün çatışmasının hızlanması ve yoğunlaşmasıdır. Dolayısıyla Veblen'in izinde teknolojiden, gelişmeden ve teknolojik gelişmeden ne anlaşılması gerektiği, içinde yaşanılan çağ içinde yeniden sorgulanmalıdır. Bu çağdaş sorgulamanın içinde Veblen'in tarih öncesi olarak işaretlediği eski toplumların yapıları, teknoloji kültürü, ürünleri ve doğayla olan etkileşimi de bu iki kültürün çelişkisinde göz önüne alınmalıdır. Bu bizi kapitalizmin ve piyasa ekonomisinin ötesinde uzun tarihin (longue durée) evi olan maddi yaşama geri götürmektedir. Bu geriye gidiş ya da maddi yaşamın derinliklerine inişin nedeni tarih merakından kaynaklanmıyor; kapitalizmin krizlerinin yoğunlaştığı ve söz konusu iki kültürün çatışmasının arttı̆̆ı, gelecek fikrinin her iki taraf için de giderek belirsizleştiği bir zamanda, dünya nüfusunun önemli bir kesiminin çekildiği alan olmasından ileri geliyor. Bunun için Braudel'in kapitalizm, piyasa ekonomisi ve maddi yaşam arasındaki bölünmeye bağlı olarak kapitalizmin tarihini ele aldığı ve burada teknolojiye özel bir parantez açtığı üç ciltlik magnum opus'u Uygarlık ve Kapitalizm (Braudel, 1981; 1982; 1984) adlı eserine dönmek isabetli olacaktır.

\section{Braudel: İktisadi Uygarlığın Üç Katmanı ve Teknoloji}

Braudel İkinci Dünya Savaşı sırasında Almanya Lübeck'teki beş yıllık hapishane esaretinde kaleme aldığı ve 1949'ta yayımlanan II. Felipe Dönemi'nde Akdeniz ve Akdeniz Dünyası (1972) adlı eserinden otuz yıl sonra Uygarlık ve Kapitalizm'i 1979'da okuyucuyla buluşturmuştur. İki eserde dikkat çeken ortaklık Braudel'in 1556'da başlayan yaklaşık elli yıl süren II. Felipe döneminin Akdeniz tarihi ile on beşinci ve on sekizinci yüzyıl arasındaki kapitalist uygarlığın oluşum ve gelişim tarihini ele alırken aynı analitik yapıya bağı kalmasıdır. Tarihsel analizi Rankegil belgeye dayalı olay anlatıcılığı ve aktarıcılığından çıkartıp, olayları ve kişileri evrensel tarih analizinde görecelileştiren üç boyutlu ve katmanlı analitik bir tarihsel yapı geliştirmiştir. 
Buna göre bir hükümdarın dönemindeki Akdeniz sadece kişilerin kararlarına göre şekillenen savaş 'olayları' ile anlatılamaz. Aynı şekilde Akdeniz'deki savaşların, bu tarihin kişilerinin ve kısa dönemli olayların tarihi de sadece bunlara bakarak açıklanamaz. Bu olayların altında insan yaşamının ve hareketinin oluştuğu kültür, toplum, ekonomi ve siyaset yatağı vardır. Ancak Akdeniz dünyası, içindeki olaylar ve bu olay devinimlerinin altında onların hazırlayıcısı kültürel, toplumsal, ekonomik ve siyasal yaşamla da tam olarak ya da bütünsel biçimde açıklanamaz. Akdeniz ayrıca bir coğrafya olarak, bu coğrafyanın unsurları yarımadalar, bu yarımadaları oluşturan dağlar, dağların etekleri, tepeler, düzlükler, yaylalar, ovalar, kıyılar, sahiller, adalar ve sonra iklimi, rüzgârları ile göz önüne alınmalıdır. Braudel için Akdeniz'in coğrafyası üzerinde kentlerle, yollarla, göçlerle, ekonomilerle, yönetim ve devletlerle inşa edilmiş insan yaşamı bir Akdeniz dünyası kurmuştur. Bu dünyanın içindeki devletler arası siyasal rekabet ve savaşlar Akdeniz'in bir kısmıdır. Bu son olay halkası ve altındaki pazar, kültür, maddi uygarlık katmanı Akdeniz'in nesnel coğrafyasından bağımsız ele alınamaz. Annales Okulu’nun ikinci kuşak öncü ismi Braudel'in tarih yazımında yarattığı dönüşüm Akdeniz'de maddi ve coğrafi olanı, değişmez/durağan yapıları ön plana getirmiştir. Braudel'in tarihe yaklaşımının bu analitik yapısına göre Akdeniz tarihi kendi maddi coğrafi yapısından başlar, bu yapıya hemen bitişik gelişen insan yaşamının doğal ekonomisi ve bu doğal yapıdan uzaklaşıp para ekonomisine göre şekillenen ekonominin ve siyasetin karmaşık örgütlenme ve yapılma tarzına uzanır; oradan yapının kapitalistik formlarla buluştuğu ve büyük devlet adamlarının, kahraman komutanların Akdeniz'in sözcüsü gibi göründüğü savaşlarla sonuçlanır. Akdeniz sonuncusundan başlayarak değil, ilk maddi verili yapıdan başlanarak anlatılabilir ya da daha doğrusu açıklanabilir.

Braudel'in tarihi uzun dönem içinde ve global olarak yakalayan bu analitik yaklaşımı on beşinci ve on sekizinci yüzyıl arasında oluşumunu ve gelişimini incelediği kapitalizmin anlaşılması için de geçerlidir. Kapitalizm, Braudel için uygarlığın adını koyan, uygarlığın tepesinde onun üst yönetim kademesinde yaşayan, ancak Akdeniz'de ikinci katman olarak belirlenen piyasa ekonomisi üzerinde yükselen bir davetsiz misafir olarak bir anda gelip evin en üst katına yerleşmiştir. Braudel Akdeniz'deki analizine bağlı kalarak modern uygarlığı aynı şekilde üçe bölmüş ve bunu bir eve benzeterek en üst katı kapitalizm, orta katı piyasa ekonomisi ve en alt katı maddi yaşam ya da maddi uygarlık olarak belirlemiştir. Kapitalizm kapitalizme bakarak anlaşılamaz, tıpkı Akdeniz'in sadece savaşlarla, hükümdarlarla ve komutanlarla açıklanamayacağı gibi. Kapitalist uygarlığı yalnızca piyasa ekonomisi ile birlikte, ona indirgeyerek düşünmek de sonuç vermez. En alt ve en geniş katman, en uzun tarihe sahip maddi yaşam 
Akdeniz coğrafyası gibi analizde ilk planda olması gerekir. Maddi kültür ve gündelik yaşam analizlerinin önem kazandığı günümüzde Braudel'in piyasa ekonomisi ve kapitalizm ile birlikte düşündüğü maddi uygarlık analizi ilişkisel bir kuramsal ve tarihsel çerçeve sunmaktadır.

Uzun tarihin (longue durée) alanı olan maddi yaşamın, piyasa ekonomisi ve kapitalizme kıyasla sosyal bilimlerde kuramsallaştırılma denemeleri daha geç ortaya çıkmıştır. Braudel böyle bir denemede bulunmamıştır ve hatta neoliberalizmin doğumunda yazan bir tarihçi olarak kapitalizmin hâlâ maddi kültür ve gündelik yaşamla temasının dolaylı ve mesafeli olduğuna inanmıştır. Kapitalist ve kapitalist olmayan yapıların birlikte var olduğuna işaret etmiş ve hatta kapitalizm kendi yapısını istikrarı kılmak için kapitalist olmayan yapıları ve kültürü korumak ya da en azından teğet geçmek durumunda olduğunu vurgulamıştır. Kapitalizmin neoliberal aşamasının ayırıcı özelliği ise kapitalist olmayan kültürlere ve yapılara kapitalizmin yağmacı ve istilacı bir kültür olarak nüfuzu ve saldırısıdır. Bu bizi tekrar Veblen'in kuramına geri getirmektedir. Veblen ve Braudel'in kapitalizm tanımı da benzerlik göstermektedir. Veblen'in tarif ettiği biçimiyle kapitalizmi hızı olayların yaşandığı spekülatif bir kazanç alanı olarak gören, kazanç için mutlaka sanayi sistemi ile yetinmeyen, sanayinin teknolojik donanımının piyasa değeri ile daha çok ilgilenen, konjonktüre göre kârlı olduğunda sanayi üretimine yönelen esnek, uyum kabiliyeti yüksek, iktisadi ve toplumsal yaşamı hiyerarşik olarak örgütleyen bir toplumsal kümedir kapitalizm. Braudel (1981, s. 24) bu kümenin bir "kargaşa alanı" olarak işinin esas biçimde piyasa ekonomisini baltalayıp onun rekabetçi işleyişini bozarak çalıştı̆̆ını ve yüksek kârlarını bu yolla elde ettiğini düşünmektedir. Braudel'in kapitalizm ile piyasa ekonomisini ayırması iktisat eleştirisi bakımından son derece değerli ve iktisadi yaşamı anlamak için yararlıdır. Bu noktada vurgulanmalıdır ki Braudel'i serbest piyasa ekonomisini ideal ekonomi modeli olarak soyutlayan liberal iktisat öğretisinden ayıran temel düşünce şudur: Rekabetçi piyasa ekonomisi iktisadi uygarlığın belirli bir konumunda ve alanında yer tutmaktadır. Piyasa ekonomisinin bu rekabetçi yapısının alt katmanlarında maddi yaşama doğru açılan yerel pazarlara dayalı ekonomiler, üst katmanlarında ise yüksek kapitalizme doğru açılan mikrokapitalist alanlar yer alır; ve buna göre piyasa ekonomisi maddi kültür ile iktisadi, askeri ve siyasi güç birikim alanı olan kapitalizm arasındaki konumunun gerçeğinde kavranabilir. Dolayısıyla, serbest piyasa ekonomisi Braudel'in düşüncesinde bir ideal sistem olarak yüceltilmek yerine maddi yaşam ve kapitalizm arasındaki konumunda görecelileşmektedir. İdealden ziyade bu çok katmanlı toplumsal ve iktisadi ilişki bağlamında bir realite ve olgu olarak rekabetçi serbest piyasa ekonomisi söz konusudur. Braudel'in analizini ve katkısını değerli kılan diğer nokta tüm bu 
uygarlığın temelinde maddi yaşamın olduğu, tarihin ve maddi yaşamın uzun dönemde son sözü söyleyecek olmasına bağladığı düşüncesidir. Bu doğrultuda bir açıklama peşindeki sosyal bilim denemeleri kapitalizmin ve piyasa ekonomisindeki ardışık ve bileşik krizlerin maddi ve gündelik yaşamın derinliklerine büyük bir insan nüfusu ihraç etmesi gerçeğine daha fazla önem vermek durumundadır.

Braudel'in tarihsel yöntemi üzerine inşa ettiği kapitalizm ve uygarlık analizine göre üç katman birbirinden birbirine karşıt olacak şekilde farklıdır. Bu özellikle kapitalizm ve piyasa arasındaki ilişki için geçerlidir. Kapitalizmi karşı-piyasa olarak tanımlayan Braudel için kapitalizm ve piyasa ekonomisi farklı yapısal özelliklere, zamansalıklara, eylem kalıplarına ve iktisadi kazanç hacmine ve türlerine sahiptir. Buna göre spekülatif yüksek kazançların alanı olan kapitalizm, orta ve küçük ölçekli işletmelerin hâkim olduğu ve rekabetçi bir yapıda normal (ılımlı) kârlar elde edilen piyasa ekonomisi ve son olarak kendine yeter ihtiyaç ekonomisi içindeki maddi yaşam söz konusudur. Yerleşik iktisadın hatası toplumsal yapıda belirli bir alan kaplayan ve normal (ılımlı) kârlar elde edilen rekabetçi ekonomiyi ekonominin bütünü olarak soyutlamasıdır. Piyasanın kapitalizm ve maddi yaşam ile ilişkisi anaakım iktisat teorisinde tamamen kesilmiştir; dolayısıyla toplumsal yaşamın diğer kurumları da açıklanamaz hale gelmiştir. Oysa, belirtildiği üzere, piyasa ekonomisinin yukarı bölgelerinde kapitalizme yakın yerlerde mikro-kapitalizm alanları ve aşağıya doğru maddi yaşama yakın yerlerde alt pazar ekonomileri oluşmaktadır. Bu üç toplumsal katmanın farkı sadece iktisadi eylem tarzları ile kazanç yapıları ve ölçekleri bakımından ortaya çıkmaz; aynı zamanda zamansallıkları ve yapının daha genel özellikleri bakımından ayrışılar. Kapitalizm esnekliğin, hiyerarşinin, yeni durumlara uyum gösterme potansiyelinin yüksek olduğu, iktisadi oyunun rekabetçi kurallarını sürekli bozup yüksek kârlar elde edilen ve buna göre konjonktürel bir zamansallık içinde devinim gösteren bir toplumsal kümedir. Piyasa ekonomisi rekabetin hâkim olduğu, normal (ılımlı) kârların elde edildiği, iktisadi olayların birbirini dengeye getirdiği ve simetrik dalgalanmaların gerçekleştiği, zamansallık bakımından kısa dönemin hâkim olduğu bir toplumsal kümedir. Maddi yaşam ise ihtiyaç temelli ekonomisinde kendine yeter kazançların ve takasın oluştuğu, durağanlığın temel yapısal özellik olarak korunduğu, uzun dönemin (longue durée) alanıdır (Gürkan, 2005; Özveren, vd., 2006).

Uygarlığın iktisadi yapısıyla birlikte teknoloji Braudel'in bu şemasına göre düşünüldüğünde karşımıza bazı sonuçlar çıkmaktadır. Her şeyden önce tek tip bir teknoloji alanının ve ona tekabül eden türdeş zamansallıkların, eylem kalıplarının, kazançların, aktörlerin, 
yapısal özelliklerin olmadığı görülür. Teknolojiyi harekete geçiren, ister yenilik ister icat olsun, motivasyonların ve maddi koşulların farklılaşması bu şemaya göre izlenebilmektedir. Maddi yaşamın aktörlerinin geleneksel olarak büyük çoğunluğu köylülerdir ve ayrıca ilkel teknolojik tarım araçlarıyla geçimini sağlayan kırsal alanda yaşayan nüfustur. Birleşmiş Milletler'in World Urbanization Prospects (2014, s. xxi) raporuna göre bu nüfus dünya nüfusunun yüzde kırk beşine tekabül etmektedir ve 2050 yılı itibariyle bu oranın yüzde altmış altıya yükseleceği beklenmektedir. Kapitalizmin piyasa ekonomisi ile birlikte maddi yaşamın içine doğru istilası piyasa ekonomisinin rekabetçi yapısını daraltırken maddi yaşama çekilen insan nüfusunu büyütmektedir. Bu durum kapitalizm katında finansal gelişmelere bağlı olarak gelişen teknolojik devrimlerin yaşandığı alanın karşısında ilkel tekniklerle ve teknolojilerle bütünleşen bir nüfusun çoğalması gibi bir durum yaratmaktadır. Bu tabloda çelişkinin tarafları kapitalizmle maddi yaşam olarak görünmektedir. Bir başka deyişle, kapitalizm çelişkilerini maddi yaşama taşımaktadır ve Braudel'in analizinde bütünlük arz eden maddi yaşamın yapısı bir taraftan kendi içinde kapitalistleşen ve kapitalistleşmeyen kesimler arasında parçalanırken diğer taraftan (kapitalistleşen/kapitalistleşmeyen) maddi yaşam ile kapitalizm arasında çelişkilerin ve çatışmaların yeni örüntüleri, bunlara uygun yeni yönetimsel stratejiler gelişmektedir. Bu bakımdan teknolojiyi ve ürünlerini pazar ve piyasa ekonomisi ile kapitalizm bağlamında değerlendirirken aynı mesainin fazlasının Braudel'in tarif ettiği maddi yaşam ve teknoloji ilişkisi için harcanması mantıklı görünüyor.

Her şeyden önce maddi yaşamdaki teknolojik motivasyonun arkasında insanın temel ihtiyaç sistemi ile demografik baskı, iklim ve coğrafi şartlar yatmaktadır. Bu motivasyonlar piyasa ekonomisi için yüksek ücretler iken kapitalizm için düşen kârlar, artan ücretler ile spekülatif kazançların elde bıraktığı fazla paradır. Maddi yaşamın teknolojiye yaklaşımı ilerlemeye dönük değildir; ihtiyaçlar, nüfus, iklim ve coğrafi şartlar bunu gerekli kıldığında ilkel düzeyde yenilikler yapılır. Kapitalizmin teknolojik devrimlerinin ve piyasa ekonomisinin adımsal yeniliklere dayalı teknolojik ilerlemesine karşın maddi yaşamdaki teknolojinin önündeki engeller doğaldır ve aşılması zorludur. Braudel bu nedenle maddi yaşamı mümkünün sınırlarındaki yaşam olarak karakterize etmektedir. Teknoloji mümkünün sınırları dâhilinde değişim göstermektedir. Bu durum kısmen alt katmanlarında pazar ekonomisi için de geçerlidir. Özellikle teknolojinin ve ekonominin topluma gömülü yapısının hâkim olduğu yerde ve zamanda bu sefer doğanın olmasa da toplumun ihtiyacı doğrultusunda pazar ekonomisi icatlarını ve yeniliklerini sunmaktadır (Braudel, 1981, s. 435). Pazar ekonomisi ile maddi yaşamın doğal ve biyolojik 
sınırlarından toplumsal sınırlara geçmiş oluyoruz; bu sınır kapitalizm için sürekli teknolojik devrimle aşılması gereken kârlılık sıkışması ve/veya iş̧̧i sınıfı mücadelesinden kaynaklanmaktadır. Kapitalizm teknolojik devrimlerle çözdüğü ya da ertelediği iktisadi bunalım ortamında bu yeni teknolojiler yaşamın kolaylaştırıcı yeniliklerini hızlıca sunarken, bu kolaylıklardan yararlanamayacak ve ilkel tekniklerle ve ürünlerle bütünleşen ve kapitalizmin kırk yıllık neoliberal sürecinin daralttığı alanlarda bunun arayışına yönelen, yönelmek zorunda olan yaşamlar da çoğalıyor. Pazar ekonomisinin içinden doğan siyasal ve sosyal toplum maddi yaşamın uzun döneminin halklarıyla ve kültürüyle daha yakından tanışıyor. Bu bütünleşme ve yoğunlaşma aynı zamanda maddi ve gündelik yaşamın idaresi için kapitalizmin disiplin iktidarını ve artan sağ popülist otoriterlik ile hükümranlık tipi iktidarı bugün daha fazla gündeme taşıyor. Bir taraftan kapitalizme tabi piyasa ekonomisinden ötelenenlerin alanı haline gelen dışlanmışların yeri olarak maddi yaşam ve dolaylarındaki pazar ekonomileri, diğer taraftan buralarda biriken yoksulluğu çözme ve yönetme amacıyla işe koşulan ve eskide kaldığı düşünülen disipliner ve hükümranlık tipi iktidar tekniklerinin uygulandığı alan olarak maddi yaşam söz konusudur. Veblen ve Braudel doğrultusunda teknolojinin nedenlerini ve sonuçlarını bu bölünmüş üç katmanlı uygarlık içinde sosyal faktörlerin etrafında değerlendirmek gerekiyorsa, bu faktörlerin içinde buraya kadar yer yer işaret edilen ama diğerleri kadar analize konu edilmeyen 'iktidar' konusunu da bu analitik ve tarihsel çerçeve içine yerleştirmek gerekiyor. İktidar özelinde bu çerçeveye bizi taşıyacak olan Foucault'dur.

\section{Foucault ve 'Teknoloji Olarak Iktidar'}

Foucault iktidarı anlamanın yolunun iktidarı kimin elinde tuttuğu sorusundan, izin veren, yasaklayan ve bastıran yasa sisteminden, hukuksal bir iktidar kavrayışından ve sosyolojisinden, kısaca olumsuz bir iktidar anlayışından vazgeçmekle mümkün olduğunu dile getirirken iktidarın yeni kavranma yolunun kavramsal aracı olarak teknolojiye işaret etmektedir. Amacı, kendi sözleriyle, "[s]adece hukuksal ve olumsuz bir iktidar anlayışını değil, bir iktidar teknolojisi anlayışını da içeren bir analiz" geliştirmektir (Foucault, 2019b, s. 137). Bu, güncel bir iktidar meselesidir çünkü iktidarı kavramanın yolu olarak yasaklamanın ve bastırmanın "ayrıcalığından kurtulmayı deneyen, teknoloji olarak iktidar biçiminde tüm bir yeni anlayışın ortaya çıktığını görüyoruz" (Foucault, 2019b, s. 138). "Bireylerin siyasi teknolojisi" (Foucault, 2019a) başlıklı 
yazısının kapanış sözleri Foucault'nun iktidarı teknoloji olarak kavramasının nedenlerini bilgiiktidar ilişkisinde serimlemektedir:

\begin{abstract}
Siyasi rasyonelliğimizin temel özelliği bence şu olgudadır: Bireylerin bir cemaate veya bir bütünlüğe dâhil olması giderek daha güçlenen bir bireyselleşme ile bu bütünlüğün sağlamsallaşması arasındaki sürekli bir karşılıklı bağlantının sonucudur. ... [T]oplumbilimin ortaya çıkışı ne bu yeni siyasi rasyonelliğin ortaya çıkışından ne de bu yeni siyasi teknolojiden soyutlanabilir. Etnolojinin sömürgecilikten doğduğunu herkes bilmektedir (ama bu emperyalist bir bilim olduğu anlamına gelmez); aynı şekilde, eğer insan -yaşayan, konuşan ve emek üreten varlıklar olarak biz- diğer çeşitli bilimler için bir nesne haline geldiyse, bence, bunun nedenini bir ideolojide değil, toplumlarımızın bağrında yarattığımız bu siyasi teknolojinin varlığında aramak gerekir (Foucault, 2019a, s. 118-119).
\end{abstract}

Foucault teknoloji ve iktidar arasındaki kavramsal ilişkiyi teknolojinin insan ve toplumsal yaşam üzerindeki baskıcı gücünü ve olumsuzluğunu vurgulamak ve açığa çıkarmak için kullanmıyor. Tam tersi teknoloji kavramı ile insanın bireysel ve toplumsal yaşamının üretimini açıklamak, iktidarın üretkenliğini açığa çıkarmak için teknoloji kavramına yöneliyor. Dolayısıyla, Foucault iktidarın geleneksel olumsuz kavrayışlarından kaçınmanın bir yolu olarak teknoloji terimine merkezi bir yer vermiştir. Bu bağlamda, devlet oluşumu ile polis idaresi ve bilimi üzerinden iktidarın yapısında ve siyasal rasyonalitesindeki dönüşümü Foucault on altıncı yüzyıldan itibaren on sekizinci yüzyılın ikinci yarısındaki eşikten geçerek yirminci yüzyıla uzanan bir dizi değişim süreci üzerinden somutlamaktadır. Bir taraftan nüfusun salt bireylerin bedensel denetiminden hem daha kapsamlı biyolojik özelliklerine doğru hem de sosyal bütüne dâhil olması bakımından bir dönüşüm yaşanmış, diğer taraftan yönetim ve siyasal rasyonalitedeki bu dönüşüme paralel olarak bilgi yapılarında dönüşüm gerçekleşmiştir. Foucault için, bilindiği üzere, bilgi ve iktidar arasında yakın bir ilişki vardır. Bilgi, devletin ve siyasi rasyonalitenin varlığını ve gelişimini mümkün kılan temel unsurdur. On sekizinci yüzyılın ikinci yarısından itibaren politik ekonominin, biyolojinin ve dilbilimin sergilediği dönüşüm insanın iktidar teknolojileri tarafından nesneleştirilip yönetimini mümkün kılmaktadır. Dolayısıyla siyasi rasyonalitenin incelenmesi uygulamadaki iktidar ve yönetim teknolojilerinin incelenmesi ile bunlara koşut gelişen bilgi yapılarındaki dönüşümün tespitine bağlıdır. Devlet siyasi ve idari bir 'yapı'dan ya da araçtan önce, istatistik (statistics: state science) gibi spesifik bilgi ve bilme biçimlerinin sonucu bir yönetimsel aparat ya da bilgi-iktidar dispozitifidir.iii Anlaşılacağı üzere teknoloji terimi burada sadece uygulamadaki araçları, kurumları, somut eylemleri ve eylem tarzlarını değil, siyasi bakışı ve düşünümü ile bilgi ve bilme biçimlerini kapsayan, bunların arasında bağlantılar kuran ilişkisel ve dinamik bir iktidar kavrayışının kavramsal aracıdır. 
Dolayısıyla, Foucault'nun yazılarına yayılmış teknoloji terimini iktidar, siyaset, devlet, yönetim, bilgi gibi kavramların ardından kullanması (iktidar teknolojileri, siyasal teknolojiler, devlet ve yönetim teknolojisi gibi) ve onları bu kavramla nitelemesi iktidarı ilişkisellik bütünü ve hareketi içinde dinamik bir biçimde yakalamak ve dinamik bir analiz geliştirmek içindir.

Foucault'nun bahsettiği iktidar teknolojilerinin içinde ne olduğuna bakmak için yine "Bireylerin siyasi teknolojisi" (Foucault, 2019a) yazısının hemen başına dönmek gerekir. Foucault burada bu yazısının konusu olmayacak bir başka teknolojiden bahsetmektedir: "kendilik teknikleri" ya da "kendilik teknolojileri" (technologies of the self) (Foucault, 2001a, s. 403). Kendilik teknolojileri Foucault'nun 1980 sonrasına denk gelen etik üzerine çalışmalarında yönetim sorunsalını kişinin kendisi ve diğerleriyle yönetimsel ilişkisi bağlamında açıklayan bir diğer teknolojik iktidar terminolojisidir. Foucault'nun çalışmalarına yayılan iktidar teknolojisi ya da 'teknoloji olarak iktidar' kavramsallaştırması bireysel ve toplumsal düzeydeki iktidar ilişkileri ile bu ilişkileri düzenleyen daha genel düzeydeki iktidar kipleri ya da yapıları şematik bir gösterim ile açıklanabilir. Thomas Lemke (2011) Foucault'nun bireysel ve kolektif düzeydeki iktidar ilişkileri açısından işaret ettiği farklı iktidar teknolojilerini aşağıdaki tablo ile sunmaktadır.

Tablo 1: Farklı Biyopolitik Teknolojiler

\begin{tabular}{lcc}
\hline \hline \multicolumn{1}{c}{ Özne biçimi } & Birey & Kolektif \\
$\begin{array}{l}\text { Yaşam biçimi } \\
\text { zoé (fiziki varlık) }\end{array}$ & Beden Teknolojileri & Nüfus Teknolojileri \\
bios (ahlâki ve siyasal varlık) & Kendilik Teknolojileri & Toplum Teknolojileri \\
\hline
\end{tabular}

Agamben'in iki farklı yaşam biçimi olarak adlandırdığı zoé ve bíos ayrımını izleyen Lemke bu tablo ile Foucault’nun iktidar ilişkilerine dair tanımladığı teknolojileri, bireylerin yaşamlarının fiziki ve ahlâki/politik düzlemlere denk düşen özneleşme tarzlarının bireysel ve kolektif ölçeklerdeki kesişiminde sunmaktadır. Buna göre bireysel özneleşmenin fiziki ve ahlâki/politik matrisi, sırasıyla disiplin iktidarı ile kişinin kendinin yönetiminin teknikleri ile mümkünken, bireyin kolektif özneleşmesi nüfus ve toplum olarak kurulmasına imkân tanıyan makro ölçekteki düzenleme teknolojileri ile olanaklıdır. Nüfus burada disiplin iktidarının daha gelişmiş bir makro ölçeğini gösterirken, bireyin toplumsal kuruluşu yukarıda bahsedilen bireyin toplum biçiminde politik kuruluşuna ve özneleşmesine işaret etmektedir. Foucault'nun yaşam ve özneleşme tarzlarının mikro ve makro ölçekteki bu kurulumu ve yönetimi tablonun gösterdiği gibi eşanlı bir iktidar matrisi içinde gerçekleşir. İktidar bireylerin yaşam ve özne(leşme) formları üzerinden bedenlerinden ve benliklerinden nüfusun biyolojik varlığına ait bir nesne ve topluma ait politik 
varlıklar olarak çapraz geçişler yapar. Iktidar bu bakımdan farklı ölçeklerde farklı yönetim tekniklerini bireylerin yaşam ve özneleşme formları üzerinden işe koşan dinamik bir süreçtir. Bu süreci daha genel düzeyde iktidar kipleri ya da yapıları açısından Foucault (2013) on altıncı yüzyıldan itibaren gelişimini kronolojik olarak tespit ettiği ancak bu kronolojiye bağlı olarak birbirlerinden kopuk görülmemesi gerektiğini belirttiği hükümranlık, disiplin ve liberal güvenlik yönetim tarzı ile açıklığa kavuşturmaktadır. Mekânsal dağılımları, zamansallıkları, yönetimi ve iktidarın konularını sorunsallaştırma biçimleri, yasayı, cezayı ve kuralı anlama tarzları, özneye yaklaşımı, cezalandırma teknikleri, iyinin ve kötünün ne olduğu, adil ve meşru olanın belirlenimi, dayandıkları bilgi yapıları ve bilme biçimleri, iktidarı uygulama ve buna göre iktidar tekniklerindeki seçimleri bakımından birbirlerinden açık bir şekilde bu üç iktidar kipi ayrılabilmektedir. Ancak tıpkı bireylerin bireysel ve toplumsal kuruluşları ve yönetimlerinde olduğu gibi eşanlı iktidar teknolojilerinin iş başında olması gibi, Foucault bu noktada da bu teknolojileri iş başına koyan daha genel düzeydeki bu üç iktidar kipinin birbirini yerinden etmektense iç içe geçtiğine dikkat edilmesi gerektiğini belirtir. Buna göre bireylerin bireysel ve toplumsal kuruluşunda ve yönetiminde aynı anda üç iktidar kipi de geçiş yapmaktadır. Bu bakımdan neoliberal kapitalizmin güncelliği içinde neoliberalizmi salt piyasa ekonomisine temellenen yönetimsellik tarzı olarak değil, aynı zamanda hükümranlık ve disiplin iktidarının bu liberal yönetimin içine nasıl dâhil olduğu ve ağırlık kazandığını gözlemlemek gerekmektedir.

Foucault'nun yukarıda sunulan iktidarı teknoloji olarak kavrayışındaki temel sorunlardan birinin özne merkezli olduğu ve insanın bilgi-iktidar teknolojileri vasıtasıyla nesneleşme ve yönetilme tarzlarını açıklarken daha materyalist bir yaklaşım içinde insan-nesne ilişkisine değinmediği, bilgi-iktidar/yönetim-etik ekseninde yürüttüğü çalışmalarının insan-nesne ilişkisini gözden kaçırdığını ve bunun materyalist bir açıklama sunma potansiyelini azalttığı ve Foucault'nun analizini insan-merkezli (antroposentrik) bir çizgide tuttuğu yönünde eleştiriler bulunmaktadır. Bu eleştirmenlerin başında yeni materyalizmin iv öncü isimlerin Karen Barad (2007) gelmektedir. Foucault'nun iktidar çözümlemesinde insanın nesnelerle/maddeyle ve doğayla ilişkisini göz ardı etmesi Barad’a (2007, s. 235) göre Foucault’nun “geleneksel hümanist yörünge" bünyesinde kalmasına neden olmuştur. Foucault'nun bu yönde insan-nesne arasındaki ilişkiye temellenen kapsamlı bir çalışması olmasa da bu eksikliği giderici temel bir vurgusunu gözden kaçırmamak gerekir. Bu noktada Lemke'nin (2015) Barad’ın bu tespitine getirdiği eleştirel çözümlemeyi dikkate almak yararlıdır. Lemke (2015, s. 8-12) Foucault'nun yönetimi tanımlarken salt insanın yönetimi değil, aynı zamanda nesnelerin ve insan-nesne 
ilişkisinin düzenlenmesi yönünde bir tanım getirdiğine dikkat çekmektedir. Aslında Foucault’nun Avrupa'da yönetme ve hükmetme mantığında on altıncı yüzyıldan itibaren yaşadığı dönüşümü tespit ederken bu tespitin temelinde tam da yönetimin hukuksal-hükümranlık siyasal aklına göre şekillenmiş insan-insan ilişkisinden çıkıp insan-nesne ve insan-doğa ilişkisine odaklanması yer almaktadır. İncelediği tarihsel metinlerde Foucault on altıncı yüzyıl yazarlarından Guillaume La Perrière'in yönetimi insan odaklı bir yaklaşımın dışına çıkararak insanlar ve şeylerin karmaşık ilişkisi olarak tanımlamasını gündeme getirmektedir. La Perrière'in tanımına göre "[y]önetim, uygun amaca doğru yöneltmek için sorumluluğu alınan şeylerin doğru düzenidir" (akt. Foucault, 2013, s. 86). Bu kısa tanımda göze çarpan insanlardan şeylere, hükmetmekten sorumluluğa ve yöneltmeye/yönlendirmeye, meşru olandan doğruya, fetihten düzene doğru köklü kavramsal kaymalar siyasi rasyonalitedeki büyük dönüşümün işaretleridir. Burada söz konusu olan modern iktidarın işleyişinde insan-nesne-doğa ilişkisine göre şekillenen yönetimsel dönüşümdür. Hükümranlık iktidar tipinde fethin ve hükmetmenin konusu olan topraktan ve uyruklardan, toprağın üzerindeki ve altındaki şeylerin ve bu şeylerin insanlarla ilişkisinin düzenlenmesine ve yönetimine geçiş söz konusudur. Foucault'nun sözleriyle:

La Perrière'in metninde, yönetimin hiçbir şekilde toprağa gönderme yapmadığını görüyoruz: Yönetilen, şeylerdir. La Perrière, yönetimin "şeyleri" yönettiğini söylerken ne demek istiyor? Burada mesele şeylerin karşısına insanları koymak değil, daha ziyade yönetimin toprakla değil, insanlardan ve şeylerden oluşan bir tür bileşikle ilişki içinde olduğunu göstermektir. La Perrière için yönetimin sorumluluğunu alması gereken bu şeyler şunlardır: Insanlar, fakat zenginlikler, kaynaklar, geçim kaynakları, elbette toprak (sınırları, nitelikleri, iklimi, kuruluğu, verimliliğiyle toprak) gibi şeylerle ilişkileri, bağları, kesişmeleri itibariyle insanlar. Söz konusu olan, âdetler, alışkanlıklar, yapma veya düşünme biçimleri gibi diğer şeylerle ilişkileri itibariyle insanlardır. Ve nihayet, kaza veya kötü talih, kıtlık, salgın hastalıklar ya da ölüm gibi şeylerle ilişkileri itibariyle insanlardır (Foucault, 2013, s. 86-87).

Dolayısıyla yönetim insana hükmetme, toprağı ele geçirme ve mülküne katma, ve insanı yönetme değildir. Yönetim "şeylerin insanlarla iç içe geçmesi"dir (Foucault, 2013, s. 86-87). "Burada esas öğe, insanlarla şeylerin bileşimidir ve toprak ya da mülkiyet bir anlamda bunun değişkenlerinden sadece biridir" (Foucault, 2013, s. 87). Dolayısıyla, Foucault bu yorumları ve yaklaşımıyla insan-odaklı bir iktidar teorisinden ve analitiğinden ne denli uzak olduğunu göstermiştir. Foucault'nun iktidar çözümlemesi yalnızca 'teknoloji olarak iktidar' değil, aynı zamanda insanlar ve şeyler arasındaki iç içe geçen karmaşık ilişkinin yeni bir materyalist teorisidir. On altıncı yüzyıldan itibaren yönetimselliğin bu gelişimi on sekizinci yüzyılın ikinci yarısından sonra Fizyokratlarla ve Britanyalı politik iktisatçıların elinde insan-şeyler-doğa ilişkine 
doğru daha kapsamlı bir yönetim aklına doğru ilerlemiştir. Liberalizm disiplin çağını farklı bir iktidar modalitesine taşırken insan-nesne ilişkisini kavrayacağı ve yöneteceği düzlem olarak sivil toplumun yanına 'ortam' (milieu) dispozitifini yerleştirmiştir. Ortam liberal yönetimsel aklın bireyi şeylerle ilişkisini kapatma kurumlarının dışına çıkararak doğru düzene yöneltmek için seçilen yeni aparattır. "Ortam ile ulaşılmak istenen şey, tam da bu birey, nüfus ve grupların ürettiği olaylar dizisiyle, onların etrafında olup biten nerdeyse doğal olaylar dizisi arasındaki kesişme noktalarıdır" (Foucault, 2013, s. 23). Liberalizm insan-şey ilişkisini oluştuğu ortamda olay akışı içinde yöneten bir iktidar kipidir. Piyasayı böyle bir doğal/veri ortam olarak gören liberalizm on dokuzuncu yüzyılın ikinci yarısındaki krizinden marjinalizmi doğururken neoliberalizmin insan-merkezli yönetim teorisinin temellerini atmıştır. Foucault modern iktidarın ve liberalizmin tarihini insan-merkezli bir yaklaşımla ele almak yerine tam tersine modern yönetim mantığının ve siyasal rasyonalitenin insan-nesne-doğa-olay ilişkiselliğinde geliştiğini göstermiş ve bunu iktidarın ve yönetimin çözümlenmesi için adına "olaysallaştırma" (Foucault, 2001b, s. 226) dediği yöntemsel bir çerçeveye de taşımıştır. Hem Foucault'nun yaklaşımı hem klasik liberalizmin ve öncesinin yönetimsel mantığındaki güçlü insan-nesne ilişkiselliği bugün neoliberalizmin insan-merkezli doktrinlerinin ve uygulamalarının insan, doğa ve toplum üzerindeki tahribi karşısında eleştirmenler tarafından muhalif düşünce ve tutumun hanesinde görülmesine neden olmaktadır. Klasik liberalizmin muhalif bir düşünce için sınırları aşikârdır ancak Nietzsche'nin izinde ve Marx'a yakın olacak şekilde felsefenin aşma ve yeniyi yaratma düşüncesine ve eylem pratiğine yakın bir düşünür ve eylemci olarak Foucault'nun yöntemi ve yaklaşımı liberalizmden ayrı görülmelidir. İnsanı doğa ve şeylerle hükmetme ilişkisi yerine dostane ilişki içinde yönetecek ancak henüz icat edilmemiş bilgi-iktidar/yönetim-etik eksenlerde geliştirilecek sosyalist bir yönetimselliğin gerekliliği Foucault için açıktır. Böyle bir alternatifin yönetimsel teknolojileri kapitalizmin ve piyasa ekonomisinin ötesinde ve dışında maddi yaşamın ve kültürün içinde düşünerek ve eyleme koyup denenerek oluşturulabilir.

\section{Sonuç}

Veblen, Braudel ve Foucault'nun maddi yaşam, maddi kültür ve teknoloji üzerine geliştirdikleri yaklaşımların her ne kadar yakınlıklarından ziyade farklııkları belki çok daha fazla göze çarpsa da, neoliberal tahakkümün karşısında sosyal ve iktisadi teorinin bu düşünürler arasında kurulacak köprülerle deneyime ve eyleme dönük eleştirel düşünce geliştirmesi ve bu alana bir 
katkı sunması daha önemlidir.` Böyle bir ortak eleştiri düzlemine katkı sunmaya dönük bir adım olarak yapılan bu incelemenin ele aldığı yazarların çalışmaları, maddi kültür-teknoloji ilişkisi üzerine sözü daha fazla olan arkeoloji ve antropoloji kadar düşünce sunabilmektedir. Disiplinlerarası, hatta disiplinler-ötesi bir yaklaşımı gerekli kılan maddi kültür, maddi/gündelik yaşam ve teknoloji ilişkisi üzerine olan bu inceleme toplumsal değişim, iktidar ve kapitalist ekonominin yapısı arasındaki ilişkinin mikro ve makro düzeylerde unsurlarını ve dinamiklerini gösteren ve açıklayan bir denemeyi hedeflemiştir. Ulaşılan sonuçlardan biri teknoloji ve maddi kültür ilişkisinin değişim ve süreklilikler ile süreksizlikleri içeren çoğul süreçler meselesi olduğudur. Bu değişim ve süreçleri yorumlayabilecek ve açıklayabilecek yaklaşımın Veblen'den hareketle kurumsalcı ve evrimselci bir çerçeve içinde olabileceği, Braudel'den hareketle yapısal ve global bir tarih çerçevesinde gerçekleştirilebileceği ve Foucault'dan hareketle ekonomik yapı ve zamana tanınan önem kadar aynı zamanda politik rasyonalite ve mekânsal iktidar ilişkileri ile kiplerinin çerçevesinde olabileceği gösterilmiştir. Teknolojiyi yalnızca birey ve sosyal yaşam üzerinde etkide bulunan ve tahakküm kuran sabit bir değişken gibi görmek yerine sosyal faktörlerin içinde gelişen ve onlardan biri sayan yaklaşımın gerekliliği vurgulanmıştır. Ayrıca maddi kültürün ve şeylerin durağan, pasif, sosyal yaşam içinde bir etkisi olmadığı yönündeki geleneksel düşüncenin aksine şeylerin sosyal ağlar içinde dinamik ve etkide bulunan bir konumu olduğu, nesnelerin ve maddi kültür içindeki objelerin meta fetişizminin bir yönü olarak dışsal biçimiyle bütünsel ve yekpare olarak algılansalar da, bizatihi kendi içlerinde ve yapılarında maddi ve sembolik çok yönlü toplumsal ilişkilerin taşıyıcısı olduğu yönündeki içsel ilişkiye önem veren bir yaklaşımın gerekliliği gösterilmiştir. Aynı şekilde, tarih dışı, durağan, sabit ve önemsiz görülen maddi coğrafyadan maddi yaşamın gündelik yapısına kadar farklı alanların uygarlığı açıklamadaki ve farklı bir teknoloji yaklaşımı geliştirmedeki potansiyel konumu özellikle Braudel'in katkılarıyla belirginleştirilmiştir. İçinden geçilen kriz zamanlarında gelecek fikrinin dayanaksızlığı insanları zamandan ziyade mekânsal dönüşlere daha fazla itmektedir. Teknolojinin yarattığı ilerleme düşüncesine bağlı olarak gelişen zaman-yüklü bireyler, yine kapitalizmin krizleriyle bu zamanın gelecek bağıntısını yitirmesi sonucunda 1960'larda sosyal bilimlerde başlayan 'mekânsal dönüş' paradigmasına benzer şekilde, şimdiki kuşaklar özel, doğal ve kamusal mekânların hızla yitirilişinin olumsuz etkisiyle ve bunları geri kazanma itkisiyle, Foucault'nun (2019c, s. 283) deyimiyle özellikle teknolojinin ittiği ve nesnelerle ilişkisini hızlı dönüşümlerle deneyimleyen "zamanın inançlı evlatları" olmaktan çıkıp yeniden "mekânın kararlı sakinleri" olmanın deneyimini yaşıyorlar. Artan göç hareketleri ile dünya nüfusunun 
giderek büyüyen bir kesiminin içinde uyanan sürekli göç duygusu, maddi kültürü ve gündelik yaşamı içinde oluştuğu mekânlarla, mekânsızlaşmalarla ve doğrudan kullanıma dönük objelerle ve nesnelerle yeniden sosyal bilimlerde farklı biçimde algılanmasına katkı yapmaktadır. Sosyal bilimlerin bu nüfus hareketini, hareketsizliğini, ikisi arasındaki gerilimi ve maddi kültür ile temel bileşenleri nesnelere dair yeni uyanan düşünceleri ve toplumsal duyguları takip eden, bunları yeni eleştiri düzlemlerine taşıyacak fikirlere intiyacı bulunmaktadır. Veblen, Braudel ve Foucault'nun bu çerçeve için eskide kalmış düşünürler olarak görülmesi yerine yeniden yorumlanacak düşünürler olarak ele alınması gerektiğini ve ortak çabaya bu yazının kapsamı içinde sunulandan daha fazla katkı sunacağını belirtmeliyiz.

\section{ORCID ID}

CEYHUN GÜRKAN

\section{iD https://orcid.org/0000-0002-8048-7175}

\section{Declaration of Conflicting Interests}

The author declared that there were no conflicts of interest with respect to the authorship or the publication of this article.

\section{Çıkar Çatışması Beyanı}

Yazar bu makalenin yazarlık veya yayımlanmasına ilişkin olarak hiçbir çıkar çatışması olmadığını beyan etmiştir.

\section{KAYNAKÇA}

Barad, K. (2007). Meeting the universe halfway: Quantum physics and the entanglement of matter and meaning. Durham/London: Duke University Press.

Braudel, F. (1972). The Mediterranean and the Mediterranean world in the age of Philip II. New York: Harper \& Row.

Braudel, F. (1981). Civilization and capitalism, 15th-18th century: The structures of everyday life. New York: Harper \& Row.

Braudel, F. (1982). Civilization and capitalism, 15th-18th century: The wheels of commerce. New York: Harper \& Row.

Braudel, F. (1984). Civilization and capitalism, 15th-18th century: The perspective of the world. New York: Harper \& Row. 
Foucault, M. (2001a). The political technologies of individuals. J. D. Faubion (der.), The essential works of Foucault, volume III: Power. London: Allen Lane, 403-417.

Foucault, M. (2001b). Questions of method. J. D. Faubion (der.), The essential works of Foucault, volume III: Power. London: Allen Lane, 223-238.

Foucault, M. (2013). Güvenlik, toprak, nüfus. (F. Taylan, Çev.). İstanbul: İstanbul Bilgi Üniversitesi Yayınları.

Foucault, M. (2015). Biyopolitikanın doğuşu. (A. Tayla, Çev.). İstanbul: İstanbul Bilgi Üniversitesi Yayınları.

Foucault, M. (2019a [1976]). Bireylerin siyasi teknolojisi. F. Keskin (der.), Özne ve iktidar. İstanbul: Ayrıntı, 103-119.

Foucault (2019b [1976]). Iktidarın halkaları. F. Keskin (der.), Özne ve iktidar. İstanbul: Ayrıntı, 136-156.

Foucault, M. (2019c [1967]). Başka mekânlara dair. F. Keskin (der.), Özne ve iktidar. İstanbul: Ayrıntı, 283-293.

Gürkan, C. (2005). Braudel and technological innovation process. Ankara University SBF Discussion Papers, no. 83.

Gürkan, C. (2016a). The politics of neoclassical economics: Insights from Foucault's history of governmentality. History of Economic Ideas, 24(2), 117-143.

Gürkan, C. (2016b). Foucault'da neoliberal yönetimselliğin tarihsel boşlukları: Erken neoklasik iktisat ve kamusal seçim teorisi. Felsefelogos, 63(4), 87-106.

Gürkan, C. (2016c). Braudel and Foucault on structure and event: Towards a new approach to (neo)liberalism and capitalism. InterDisciplines: Journal of History and Sociology, 7(2), 63-94.

Gürkan, C. (2020). Neoklasik iktisadın ve neoliberal iktidarın yeni bir eleştirisi için: Veblen ve Foucault ile birlikte düşünmek. Praksis, 54, yayımlanacak.

Lemke, T. (2011). Beyond Foucault: From biopolitics to the government of life. U. Bröckling, S. Krasman ve T. Lemke (der.), Governmentality: Current issues and future challenges. New York /London, 165-184.

Lemke, T. (2015). New materialisms: Foucault and 'the government of things'. Theory, Culture \& Society, 32(4), 3-25.

Özveren, E., Gürkan, C. ve Matur, E. P. (2006). Firm \& technological innovation revisited: Articulating the insights from Fernand Braudel's world economic history. The 
conference CD-book of proceedings of the 18th European Association for Evolutionary Political Economy Conference, İstanbul.

United Nations (2014). World urbanization prospects. https://esa.un.org/unpd/wup/Publications/Files/WUP2014-Report.pdf. Erişim tarihi: 20 Ocak January 2017.

Veblen, T. (1946 [1914]). The instinct of workmanship: And the state of the industrial arts. New York: The Viking Press.

Veblen, T. (1958 [1904]). The theory of business enterprise. New York: Mentor Books.

Veblen, T. (1961 [1919]). The place of science in the modern civilization. T. Veblen (der.), The place of science in modern civilization and other essays. New York: Russel\&Russel, 131.

Veblen, T. (1964 [1915]). The opportunity of Japan. T. Veblen (der.), Essays in Our Changing Order. New York: Augustus M. Kelley, 248-266.

Veblen, T. (1994 [1915]). Imperial Germany and the industrial revolution. London: Routledge/Thoemmes Press.

Veblen, T. (2001 [1921]). The engineers and the price system. Kitchener: Batoche Books.

Veblen, T. (2017a [1894]). Kadın giyiminin iktisadi teorisi. E. Kırmızıaltın (der.), Thorstein Bunde Veblen: Seçilmiş makaleler. Ankara: Heretik, 13-24.

Veblen, T. (2017b [1898]). Mülkiyetin başlangıcı. E. Kırmızıaltın (der.), Thorstein Bunde Veblen: Seçilmiş makaleler. Ankara: Heretik, 41-55.

Veblen, T. (2017c [1899]). Kadınların barbar statüsü. E. Kırmızıaltın (der.), Thorstein Bunde Veblen: Seçilmiş makaleler. Ankara: Heretik, 57-68.

Veblen, T. (2017d [1898]). Iktisat neden evrimsel bir bilim değildir? E. Kırmızıaltın (der.), Thorstein Bunde Veblen: Seçilmiş makaleler. Ankara: Heretik, 71-92.

Veblen, T. (2017e [1900]). Marjinal faydanın sınırlılıkları. E. Kırmızıaltın (der.), Thorstein Bunde Veblen: Seçilmiş makaleler. Ankara: Heretik, 177-193.

Vigo de Lima, I. (2019). Foucault on the marginal revolution in economics: Language and the Cartesian legacy. Review of Political Economy, 31(1), 60-74.

Yalvaç F. ve Erçandarlı, Y. (2020). Geç kapitalizmin ideolojik söylemi olarak yeni materyalizm: Metalaşmış 'şeylerin' egemenliği. Mülkiye Dergisi, 44(2), 261-285. 


\title{
Sonnotlar
}

\begin{abstract}
i "Kârlı ticaretin gerekleri [aşırı üretime] müsamaha etmez. Dolayısıyla, üretimin oranı ve miktarı var olan kaynakların çalışma kapasitesine, makine ve insan gücüne veya toplumun tüketebileceği mallara göre değil, piyasanın ihtiyaçlarına göre ayarlanmak zorundadır" (Veblen, 2001, s. 8-9).
\end{abstract}

ii Finansal gelişme teknolojinin gelişimini hızlandırmıştır. Ama bu gelişmenin eşitsizliklerin derinleşmesi ile el ele gitmiştir: "Bankaların veya benzer yapıdaki kredi mercilerinin verdiği avanslar işadamlarının idaresinde olan 'sermayeyi' artırmaya yarar; fakat sanayinin maddi amaçları söz konusu olduğunda, toplama bakıldığında, bu avanslar yalnızca hayali metalardır. ... Bunlar [iş adamına] sanayinin maddi araçlarının bölüşümünde göreli bir avantaj sağlar; ancak bu avanslar sanayinin maddi araçlarının geneline toplu bir katkı yaratmaz. Ödenekler hangi özellikte olursa olsun endüstriyel bir olgu değil, parasal bir olgudur; bu ödenekler sanayinin yeter derecede üretken çalışmasına değil, yalnızca sanayinin kontrolünün bölüşümüne hizmet eder" (Veblen, 1958, s. 54).

iii Örneğin, neoliberal iktidarı anlamanın Foucault (2015) için temel yolu politik ekonomide insanı nesneleştirme tarzının değişimini yakalamakla mümkündür. Klasik politik ekonomide fabrikada çalışan ve emek üreten insan temsilinden piyasa dolayımıyla tüketen insan temsiline geçiş ve piyasanın ekonomik-olmayan ilişkileri kavramanın yorumsal ve yönetimsel aracı olması burada kilit önemdedir. Foucault bu geçişi Biyopolitikanın Doğuşu’nda (2015) ordoliberalizm ve Amerikan neoliberalizmi tarihi ile detaylandırmaktadır. Ancak bilgi yapısındaki bu değişişimin 19. yüzyılın son çeyreğinde iktisat teorisindeki marjinalist dönüşümle bağına da işaret etmektedir. Bu işaretin üzerine konuyu genişleten çalışmalar için bkz. Gürkan (2016a; 2016b) ve Vigo De Lima (2019).

iv Yeni materyalizm üzerine literatür incelemesi ve yeni materyalizmin Marksist bir eleştirisi için bkz. Yalvaç ve Erçandarlı (2020).

${ }^{\vee}$ Bu yöndeki çalışmalar arasında Braudel ve Foucault arasındaki diyalogdan kapitalizmin eleştirisine yönelen bir çalışma için bkz. Gürkan (2016c). Aynı şekilde Veblen ve Foucault arasında kurulan ortak bir eleştiri hattından gelişen neoliberal iktidarın ve bu iktidarın genel bilgisi olan ve söylemsel yapısını kuran neoklasik iktisadın eleştirisi için bkz. Gürkan (2020). 